\title{
KONDISI PENCEMARAN LOGAM BERAT DI PERAIRAN SUNGAI DKI JAKARTA
}

\author{
Oleh : \\ Satmoko Yudo \\ Pusat Teknologi Lingkungan-BPPT
}

\begin{abstract}
River is a place where people do their cleaning activities and one of drinking water source and also where we could find fish. But nowadays river condition in Jakarta area are seriously polluted. The reasons of water pollution are not only domestic waste but also from industrial waste, factories take out their waste to the river without proccessing it first. One of the pollution materials is heavy metal which could have bad effect on human body. This paper analyses every element of heavy metal contain on rivers in DKI Jakarta area.
\end{abstract}

Katakunci : Pencemaran, sungai, logam berat, DKI Jakarta.

\section{PENDAHULUAN}

Sungai sebagai salah satu komponen lingkungan yang mempunyai fungsi penting bagi kehidupan manusia termasuk untuk menunjang keseimbangan lingkungan. Sebagai akibat adanya peningkatan kegiatan pembangunan di berbagai bidang maka baik secara langsung maupun tidak langsung akan mempunyai dampak terhadap kerusakan lingkungan termasuk didalamnya pencemaran sungai yang berasal dari limbah domestik maupun non domestik seperti pabrik dan industri. Oleh karena itu pencemaran air sungai dan lingkungan sekitarnya perlu dikendalikan seiring dengan laju pembangunan agar fungsi sungai dapat dipertahankan kelestariannya.

Sebanyak 13 aliran sungai yang melintas di wilayah Jakarta, 10 di antaranya bermuara di Teluk Jakarta. Jakarta sebagai ibukota negara yang berpenduduk paling padat dibandingkan kota-kota lain di Indonesia. Sejalan dengan peningkatan pembangunan dan aktivitas kota Jakarta serta perkembangan penduduknya yang meningkat dari waktu ke waktu, maka kebutuhan manusia akan air bersih juga meningkat. sementara dampak dari kegiatan pembangunan yang membuang limbah domestiknya ke sungai akan menurunkan kualitas air sungai tersebut. Jadi diperlukan pembangunan yang di khususkan untuk memperbaiki sungai dan mutu air.

Kawasan sungai sering dicemari oleh logam-logam berat yang terdapat dalam air buangan dari kawasan industri yang biasanya tidak diolah terlebih dahulu. Pencemaran logam berat seperti Besi (Fe), Mangan (Mn), Seng (Zn), Kadmium (Cd), Cromium (Cr), Tembaga (Cu), Timbal (Pb), Nikel (Ni) dan Raksa (Hg), Berdasarkan sudut pandang toksikologi, logam berat ini dapat dibagi dalam dua jenis. Jenis pertama adalah logam berat esensial, di mana keberadaannya dalam jumlah tertentu sangat dibutuhkan oleh organisme hidup, namun dalam jumlah yang berlebihan dapat menimbulkan efek racun. Contoh logam berat ini adalah $\mathrm{Zn}, \mathrm{Cu}, \mathrm{Fe}$, $\mathrm{Co}, \mathrm{Mn}, \mathrm{Ni}$ dan sebagainya. Sedangkan jenis kedua adalah logam berat tidak esensial atau beracun, di mana keberadaannya dalam tubuh masih belum diketahui manfaatnya atau bahkan dapat bersifat racun, seperti $\mathrm{Hg}, \mathrm{Cd}, \mathrm{Pb}, \mathrm{Cr}$ dan lain-lain. Logam berat ini dapat menimbulkan efek kesehatan bagi manusia tergantung pada bagian mana logam berat tersebut terikat dalam tubuh. Apabila kepekatan logam-logam ini tinggi dari biasa, logam-logam ini akan menjadi suatu ancaman bagi kesehatan manusia jika memasuki rantai makanan. Oleh karena itu pemantauan kadar logam berat dalam air sungai sangat perlu dilakukan.

\section{TUJUAN}

Tujuan dari kegiatan ini adalah untuk mengetahui kondisi pencemaran logam berat di perairan khususnya sungai-sungai wilayah DKI Jakarta.

\section{METODOLOGI} adalah :

Metode yang digunakan dalam kegiatan ini

1) Kajian Literatur. sebagai bahan rujukan agar hasil analisis dan kajian lebih efektif dan efisien sekaligus memiliki bobot ilmiah.

2) Pengumpulan Data dan Informasi. Data yang digunakan adalah data sekunder yang diperoleh dari Badan Pengelolaan Lingkungan Hidup Daerah Provinsi DKI Jakarta. BPLHD mendapatkan dari pengamatan langsung pada sungai-sungai yang ada di Jakarta dan melakukan pengambilan sampel air sungai. Dari hasil 
survey lapangan, sampel yang diambi dianalisa lebih lanjut di Laboratorium Lingkungan BPLHD Provinsi DKI Jakarta, dengan metode analisa sesuai dengan Standar Nasional Indonesia (SNI).

3) Pengolahan dan Analisis Data. Pengolahan dan analisis data dilakukan dengan membandingkan data hasil pemantauan dengan baku mutu sungai berdasarkan SK Gubernur Kepala Daerah Khusus Ibukota Jakarta No. 582 tahun 1995 tentang Penetapan Peruntukan dan Baku Mutu Air Sungai / Badan Air serta Baku Mutu Limbah Cair di Wilayah DKI Jakarta, baik untuk peruntukan air baku air minum (golongan B), peruntukan perikanan dan peternakan (golongan C) dan peruntukan pertanian dan usaha perkotaan (golongan D).

\section{TINJAUAN PUSTAKA}

\subsection{Pencemaran Air Sungai}

Air merupakan sumber daya alam yang diperlukan sebagai hajat hidup orang banyak. Semua makhluk hidup membutuhkan air untuk kehidupannya sehingga sumber daya air perlu dilindungi agar tidak tercemar dan dapat tetap dimanfaatkan dengan baik. Menurut Effendi (2000) pencemaran air adalah masuknya atau dimasukkannya makhluk hidup, zat, energi dan komponen lainnya ke dalam air oleh kegiatan manusia, sehingga kualitas air turun sampai ke tingkat tertentu yang menyebabkan air tidak berfungsi lagi sesuai dengan peruntukkannya. Sedangkan menurut Odum (1971) pencemaran adalah perubahan-perubahan sifat fisik, kimia dan biologi yang tidak dikehendaki pada udara, tanah dan air.

Sumber pencemaran air sungai dapat berasal dari berbagai jenis limbah seperti limbah industri, limbah domestik, serta kegiatan lainnya seperti pertanian, perikanan dan pariwisata. Tingkat pencemaran sungai menjadi semakin tinggi dengan meningkatnya jumlah beban pencemaran limbah yang masuk ke sungai dan juga disebabkan oleh menurunnya debit aliran sungai yang bersangkutan (BARISTAND INDAG, 2000).

Berkaitan dengan pengaruh bahan-bahan pencemar terhadap kehidupan manusia, Williams (1979) dan Supriharyono (2000), mengelompokkan bahan pencemar menjadi tiga tipe, yaitu :

1) Bahan pencemar yang bersifat patogen (pathogenics pollutants), yaitu bahan pencemar yang dapat menyebabkan penyakit pada manusia.
2) Bahan pencemar yang berkaitan dengan nilai keestetikaan (aesthetic pollutants), yaitu bahan pencemar yang menyebabkan terjadinya perubahan lingkungan yang tidak nyaman untuk indera mata, telinga atau hidung.

3) Bahan pencemaran ekomorpik (echomorphic pollutants), yaitu bahan pencemar yang menghasilkan perubahan-perubahan sifatsifat físika lingkungan.

\subsection{Pencemaran Logam Berat}

Logam berat adalah unsur logam yang mempunyai densitas $>5 \mathrm{~g} / \mathrm{cm}^{3}$ dalam air laut, logam berat terdapat dalam bentuk terlarut dan tersuspensi. Dalam kondisi alami ini, logam berat dibutuhkan oleh organisme untuk pertumbuhan dan perkembangan hidupnya (Philips, 1980 dan Effendi, 2000). Peningkatan kadar logam berat dalam air sungai umumnya disebabkan oleh masuknya limbah industri, pertambangan, pertanian dan domestik yang banyak mengandung logam berat. Peningkatan kadar logam berat dalam air akan mengakibatkan logam berat yang semula dibutuhkan untuk berbagai proses metabolisme akan berubah menjadi racun bagi organisme akuatik.

Menurut Nordberg., et.al (1986) logam berat jika sudah terserap ke dalam tubuh maka tidak dapat dihancurkan tetapi akan tetap tinggal di dalamnya hingga nantinya dibuang melalui proses ekskresi. Hal serupa juga terjadi apabila suatu lingkungan terutama di perairan telah terkontaminasi (tercemar) logam berat maka proses pembersihannya akan sulit sekali dilakukan. Kontaminasi logam berat ini dapat berasal dari faktor alam seperti kegiatan gunung berapi dan kebakaran hutan atau faktor manusia seperti pembakaran minyak bumi, pertambangan, peleburan, proses industri, kegiatan pertanian, peternakan dan kehutanan, serta limbah buangan termasuk sampah rumah tangga.

Selain bersifat racun, logam berat juga terakumulasi dalam sedimen dan biota melalui proses biokonsentrasi, bioakumulasi dan biomagnifikasi oleh biota laut. Logam-logam berat yang masuk ke dalam tubuh hewan umumnya tidak dikeluarkan lagi dari tubuh mereka. Karena itu logam-logam cenderung untuk menumpuk dalam tubuh mereka. Sebagai akibatnya, logam-logam ini akan terus ada di sepanjang rantai makanan. Hal ini disebabkan karena predator pada satu trofik level makan mangsa mereka dari trofik level yang lebih rendah yang telah tercemar (Hutabarat dan Evans, 1986). 


\subsection{Merkuri $(\mathrm{Hg})$}

Merkuri $(\mathrm{Hg})$ adalah unsur renik pada kerak bumi hanya sekitar $0,08 \mathrm{mg} / \mathrm{l}$ dan hanya ditemukan dalam jumlah yang sangat kecil dalam perairan alami. Kadar merkuri pada perairan tawar alami berkisar antara $10-100$ nanogram/liter (Moore, 1991 dan Efendi 2000). Merkuri merupakan satu-satunya logam yang berada dalam bentuk cairan pada suhu normal. Merkuri terdapat di alam dalam bentuk logam, garam anorganik dan garam organik. Dalam bentuk garam anorganik merkuri dapat menyebabkan kerusakan hati dan ginjal, karena timbunan $\mathrm{Hg}$ yang paling tinggi dalam "organ dalam" manusia terjadi di hati dan ginjal. Komponen merkuri yang paling berbahaya adalah metil-merkuri (merkuri organik), yang dapat menyebabkan kematian kelainan saraf yang tidak dapat diperbaiki dan kelainan genetika. Apabila dibandingkan dengan komponen merkuri lainnya, komponen metil merkuri mempunyai kemungkinan paling rendah terkontaminasi dalam tubuh manusia dan paling lambat diekskresikan (Supriharyono, 2000).

Merkuri terserap pada bahan-bahan partikulat dan mengalami presipitasi. Pada dasar perairan anaerobik merkuri berikatan dengan sulfur. Merkuri anorganik dapat mengalami transformasi menjadi dimetil merkuri dengan bantuan aktivitas mikroba pada kondisi aerob dan anaerob. Pada kadar merkuri anorganik yang rendah akan terbentuk dimetil merkuri sedangkan pada suhu yang tinggi akan terbentuk monometil merkuri. Pada perairan alami, kadar monometil dan dimetil pada merkuri dipengaruhi oleh mikroba, karbon organik, kadar merkuri anorganik, $\mathrm{pH}$ dan suhu. Kedua bentuk senyawa metil merkuri ini dapat dipecah oleh bakteri yang hidup pada sedimen. Metil merkuri dapat mengalami bioakumulasi dan biomagnifikasi pada biota perairan, baik secara langsung atau melalui jaring makanan (food web) (Efendi, 2000).

Jenis logam berat air raksa $(\mathrm{Hg})$ tidak termasuk yang dibutuhkan dalam proses metabolisme, peranannya belum diketahui dengan jelas pada makhluk hidup. Mereka merupakan bahan pencemar yang berbahaya akibat dari pembuangan sampah-sampah ke sungai secara berlebihan. Hal ini dapat terjadi melalui tiga cara. Pertama, akibat dari pembuangan sisa industri yang tidak terkontrol. Kedua, berasal dari lumpur minyak yang kadangkadang juga mengandung logam berat dengan konsentrasi yang tinggi. Ketiga, berasal dari pembakaran minyak (hidrokarbon) dan batubara di daratan. Mereka melepaskan logam berat ke dalam atmosfer dimana kemudian bercampur dengan air hujan dan jatuh ke dalam air (Hutabarat dan Evans, 1986).

Keracunan yang disebabkan oleh merkuri ini, umumnya berawal dari kebiasaan memakan makanan yang berasal dari sungai, seperti udang, ikan dan kerang yang telah terkontaminasi oleh merkuri. Awal peristiwa kontaminasi terhadap organisme akuatik adalah masuknya buangan industri ke dalam badan perairan. Selanjutnya dengan adanya proses biomagnifikasi konsentrasi merkuri yang masuk akan terus ditingkatkan disamping penambahan yang terus-menerus dari buangan pabrik. Merkuri yang masuk tersebut kemudian berasosiasi dengan sistem rantai makanan, sehingga masuk ke dalam organisme akuatik dan ikut termakan oleh manusia bersama makanan yang diambil dari perairan yang tercemar oleh merkuri (Palar, 1994).

\subsection{Tembaga $(\mathrm{Cu})$}

Tembaga dengan nama kimia cupprum dilambangkan dengan $\mathrm{Cu}$ merupakan unsur logam yang berbentuk kristal dengan warna kemerahan. Unsur tembaga di alam, dapat ditemukan dalam bentuk logam bebas akan tetapi lebih banyak ditemukan dalam bentuk persenyawaan atau sebagai senyawa padat dalam bentuk mineral. Pada umumnya sumber masuknya unsur logam $\mathrm{Cu}$ dalam tatanan lingkungan adalah secara alamiah dan non alamiah. Secara alamiah, Cu dapat masuk ke dalam tatanan lingkungan sebagai akibat dari berbagai peristiwa alam, seperti pengikisan (erosi) dari batuan mineral dan dari debu atau partikulat $\mathrm{Cu}$ yang terdalam dalam lapisan udara dan dibawa turun oleh hujan. Secara non alamiah, $\mathrm{Cu}$ masuk ke dalam suatu tatanan lingkungan sebagai akibat dari aktivitas manusia, seperti buangan industri (contohnya industri galangan kapal) yang memakai $\mathrm{Cu}$ dalam proses produksinya. Sebagai logam berat, $\mathrm{Cu}$ digolongkan kedalam logam berat essensial, artinya meskipun $\mathrm{Cu}$ logam berat yang beracun, unsur ini sangat diperlukan oleh tubuh meski dalam jumlah yang sedikit. Toksisitas yang dimiliki oleh $\mathrm{Cu}$ baru akan bekerja dan memperlihatkan pengaruhnya bila logam ini telah masuk ke tubuh organisme dalam jumlah besar atau melebihi nilai toleransi organisme terkait.

\subsection{Khromium (Cr)}

Logam $\mathrm{Cr}$ murni tidak pernah ditemukan di alam. Logam ini di alam ditemukan dalam bentuk persenyawaan padat atau mineral dengan unsurunsur lain. Dalam badan perairan $\mathrm{Cr}$ dapat masuk melalui dua cara, yaitu secara alamiah dan non alamiah. Secara alamiah dapat terjadi 
disebabkan oleh beberapa faktor fisika seperti erosi (pengikisan) yang terjadi pada batuan mineral. Secara non alamiah berasal dari aktivitas yang dilakukan oleh manusia dapat berupa limbah atau buangan industri sampai buangan rumah tangga.

\subsection{Nikel (Ni)}

Kadar nikel pada kerak bumi sekitar 75 $\mathrm{mg} / \mathrm{kg}$ (Moore, 1991). Pada proses pelapukan nikel, membentuk mineral hidrolisat yang tidak larut. Pada perairan, nikel ditemukan dalam bentuk koloid akan tetapi garam-garam nikel seperti nikel ammonium sulfat, nikel nitrat dan klorida bersifat larut dalam air. Kadar nikel pada perairan tawar alami sekitar 0,001-0,003 $\mathrm{mg} / \mathrm{L}$ (Scoullos dan Hatzianestis, 1989 dalam Moore, 1991). Nikel banyak dipergunakan dalam industri metalurgi, pelapisan logam, industri kimia, pembakaran minyak dan pembakaran limbah (Eckenfelder, 1989 ; McNeely et al., 1979).

\subsection{Seng $(Z n)$}

Seng termasuk unsur yang berlimpah di alam. Keberadaan seng dalam kerak bumi sekitar $70 \mathrm{mg} / \mathrm{kg}$. Kadar seng pada perairan alami sekitar $<0,05 \mathrm{mg} / \mathrm{L}$, pada perairan yang asam kadarnya mencapai $50 \mathrm{mg} / \mathrm{L}$ (Moore, 1991 dan McNeely et al., 1979. Seng atau Zinc termasuk unsur essensial bagi makhluk hidup, berperan dalam membantu kerja enzim dan tidak bersifat toksik pada manusia akan tetapi pada kadar yang tinggi, dapat menimbulkan rasa pada air. Zinc biasa digunakan dalam industri besi baja, cat, karet, tekstil, kertas dan bubur kertas (Eckenfelder, 1989).

\subsection{Besi (Fe)}

Besi atau Ferrum (Fe) adalah metal berwarna putih keperakan, liat, dan dapat di bentuk. Di alam didapat sebagai hematit. Didalam air minum $\mathrm{Fe}$ menimbulkan warna (kuning), rasa, pengendapan pada dinding pipa, pertumbuhan bakteri besi, dan kekeruhan. Besi dibutuhkan tubuh dalam pembentukan Hemoglobin. Banyaknya $\mathrm{Fe}$ didalam tubuh dikendalikan pada fase absorsi. Tubuh manusia tidak dapat mengekspresikan Fe. Karenanya mereka yang sering mendapat tranfusi darah, warna kulitnya menjadi hitam karena akumulasi $\mathrm{Fe}$. Sekalipun $\mathrm{Fe}$ itu diperlukan tubuh, tetapi dalam dosis besar dapat merusak dinding usus. Kematian seringkali disebabkan oleh rusaknya dinding usus ini. Debu $\mathrm{Fe}$ juga dapat di akumulasikan di dalam alveoli, dan menyebabkan berkurangnya fungsi paru-paru .

\subsection{Mangan $(\mathrm{Mn})$}

Mangan (Mn) adalah metal kelabukemerahan. Keracunan seringkali bersifat kronis sebagai akibat inhalasi debu dan uap logam. Gejala yang timbul berupa gejala susunan urat syaraf: insomnia, kemudian lemah pada kaki dan otot muka sehingga ekpresi muka menjadi beku dam muka tampak seperti topeng (mask). Bila pemaparan berlanjut maka, bicaranya melambat dan monoton, terjadi hyperrefleksi, clonus pada patella dan tumit, dan berjalan seperti penderita parkinsonism. Selanjutnya akan terjadi paralysis bulbar, post encephalitic parkinsonism, multiple sclerosis, amyotrophic lateral sclerosis, dan degenerasi lentik yang progresif (Peny. Wolson). Tidak ada gejala GI, saluran uro-genital (UG), kelainan ada liquor cerebro spinalis. Keracunan $\mathrm{Mn}$ ini adalah salah satu contoh, dimana kasus keracunan tidak menimbulkan gejala muntah berak, sebagaimana orang awam selalu memperkirakannya. Didalam penyediaan air, seperti halnya $\mathrm{Fe}, \mathrm{Mn}$ juga menimbulkan masalah warna, hanya warnanya ungu/hitam .

\section{HASIL DAN PEMBAHASAN}

Keberadaan sungai yang merupakan perairan umum di wilayah DKI Jakarta secara ekonomi belum termanfaatkan dan secara ekologi kualitasnya telah banyak mengalami penurunan baik disebabkan oleh limbah organik maupun limbah industri. Padahal keberadaan perairan umum tersebut apabila ditata dan dikelola dengan baik untuk kegiatan ekonomi seperti perikanan dan pariwisata dapat menjadi sumber pendapatan daerah dan masyarakat DKI Jakarta.

Perairan umum disamping memiliki fungsi ekologis sebagai penampung limpasan air pada waktu hujan juga berfungsi sebagai oase penyejuk dan penambah keindahan kota apabila dikelola dan dimanfaatkan dengan baik. Agar perairan umum di wilayah DKI Jakarta dapat dimanfaatkan dan dikelola dengan baik, maka perlu dilakukan penataan dan pendataan secara tepat kemudian dilakukan perencanaan pengelolaan dan pemanfaatannya secara tepat dengan memperhatikan aspek fungsi ekologis, ekonomis dan estetika secara tepat.

\subsection{Kondisi Logam Berat di Sungai Ciliwung}

Gambaran kandungan logam berat air sungai Ciliwung, berdasarkan pemantauan terhadap seluruh badan air dengan jumlah lokasi pemantauan sebanyak 14 (empat belas) lokasi dari hulu sungai ke hilir dengan periode pemantauan sebanyak 12 (dua belas) kali 
selama periode tahun 1999 - 2004. Sungai Ciliwung merupakan sungai dengan peruntukan air baku air minum (Golongan B) dan sungai dengan peruntukan pertanian dan usaha perkotaan (Golongan D). Untuk golongan B terdapat di titik pantau 1, 2, 2A, 3, 3A, 4, 5 dan $5 A$ sedangkan untuk golongan $D$ terdapat di titik pantau 6, 29, 29A, 30, 31, 32. Peta lokasi dan nama lokasi, dapat dilihat pada Gambar 4.

Kandungan logam berat pada sungai Ciliwung, rata-rata tahun 1999 untuk parameter seng berkisar 0,01 - 0,02 $\mathrm{mg} / \mathrm{L}$ dan untuk parameter mangan berkisar 0,01 - 0,28 mg/L yang masih memenuhi baku mutu yang ditetapkan oleh Keputusan Gubernur Provinsi DKI Jakarta Nomor 582 tahun 1995 yaitu untuk seng $1,00 \mathrm{mg} / \mathrm{L}$ dan untuk mangan $0,50 \mathrm{mg} / \mathrm{L}$ (Golongan B), 1,00 mg/L (Golongan D). Untuk parameter besi berkisar $0,30-6,63 \mathrm{mg} / \mathrm{L}$, tertinggi di titik $5 \mathrm{~A}(6,63 \mathrm{mg} / \mathrm{L})$ yang sudah melebihi baku mutu yang ditetapkan yaitu untuk besi adalah sebesar $2 \mathrm{mg} / \mathrm{L}$. Hal ini diduga karena padatnya penduduk yang tinggal di sekitar lokasi tersebut dan banyak menghasilkan limbah domestik. Selain itu banyak terdapat sejumlah industri rumah tangga dan industri kecil seperti kosmetik, percetakan, bengkel las mobil/motor, logam elektro platting dan lain-lain yang juga mencemari sungai. Setiap limbah dari pemukiman dan industri dibuang ke sungai
Ciliwung tanpa diolah terlebih dahulu.

Pada tahun 2000 - 2003 dilakukan dua kali pemantauan yaitu pada bulan April dan Juli. Kandungan logam berat untuk seng $(\mathrm{Zn})$ pada tahun $2000-2003$ berkisar antara 0,01 - 0,17 $\mathrm{mg} / \mathrm{L}$ dan masih memenuhi baku mutu yang ditetapkan oleh pemerintah. Pada tahun 2004 kandungan $\mathrm{Zn}$ menurun dan pada bulan April hampir diseluruh lokasi pemantauan (Golongan B) tidak terdapat logam ini. Untuk logam berat mangan $(\mathrm{Mn})$ rata-rata hampir memenuhi baku mutu yang telah ada, walaupun ada beberapa titik yang konsentrasinya agak tinggi seperti di titik 30 pada tahun 2002. Pada tahun 2004 konsentrasinya menurun kembali. Sedangkan konsentrasi besi di sungai Ciliwung antara tahun 2000 - 2004 cenderung tinggi pada tahun 2000 di titik 1 dan $5 A$ yang hampir mencapai $3 \mathrm{mg} / \mathrm{L}$ sedangkan pada tahun-tahun berikutnya konsentrasinya kembali menurun.

Konsentrasi logam yang berubah-ubah ini dapat terjadi karena adanya perubahan jumlah penduduk, perubahan kegiatan di sepanjang DAS dan juga karena perubahan peruntukkan lahan. Kondisi logam berat pada titik pantau di sepanjang sungai Ciliwung dari tahun 1999 s.d. 2004, dapat dilihat pada Gambar 1-2-3.

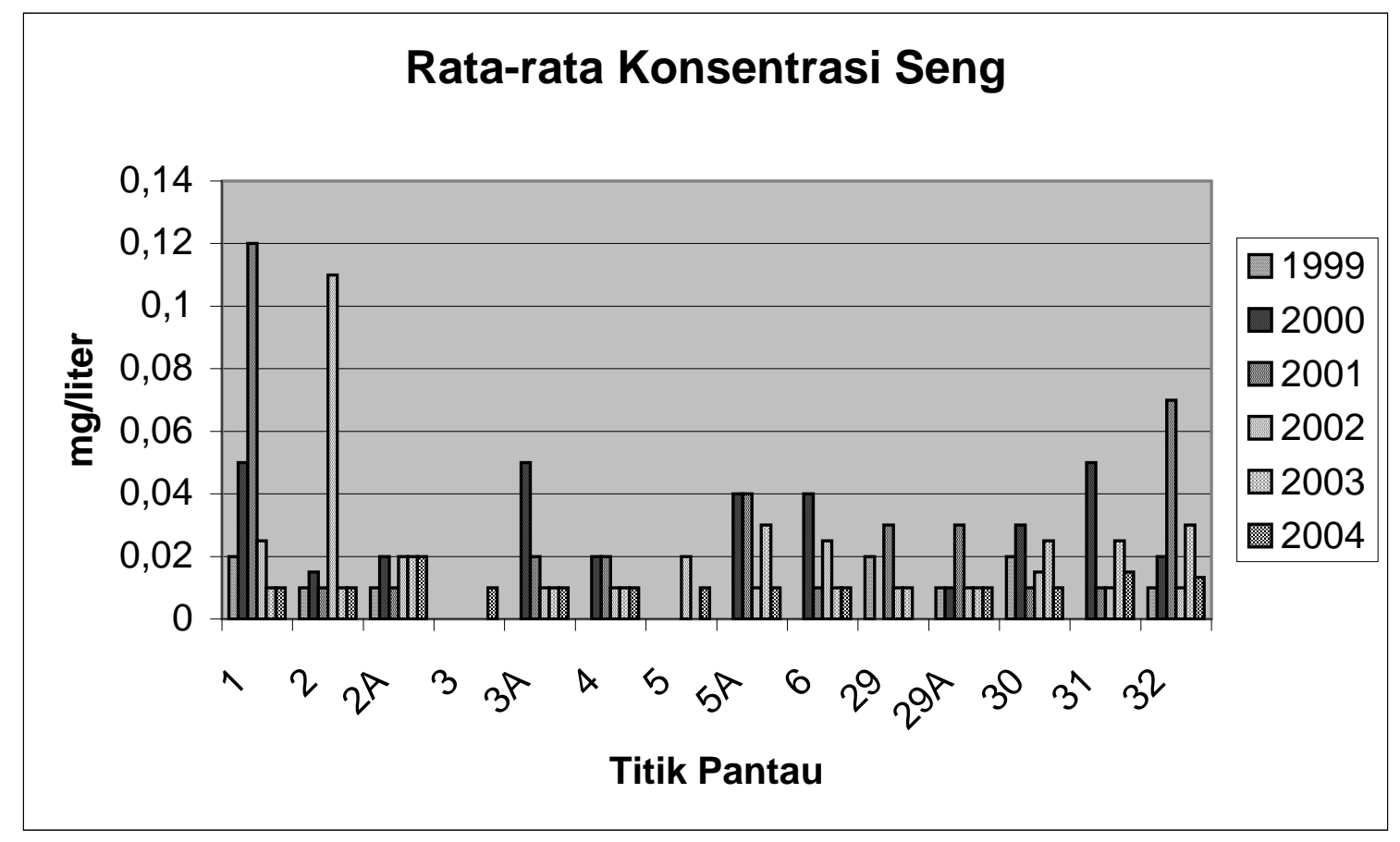

Gambar 1 : Rata-rata Konsentrasi Seng (Zn), di Titik-titik Pantau Sepanjang Sungai Ciliwung 


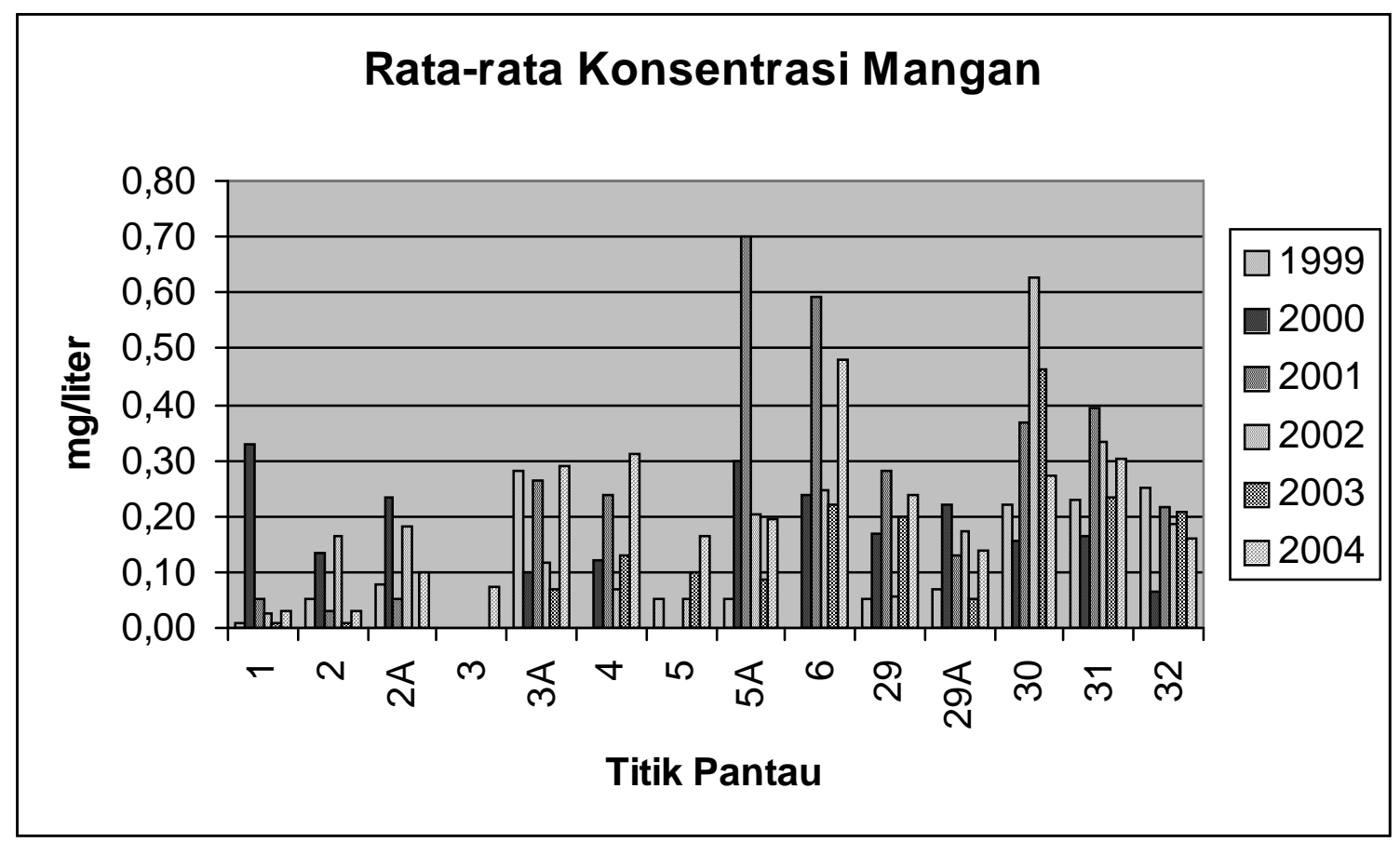

Gambar 2 : Rata-rata Konsentrasi Mangan (Mn) di Titik-titik Pantau Sepanjang Sungai Ciliwung

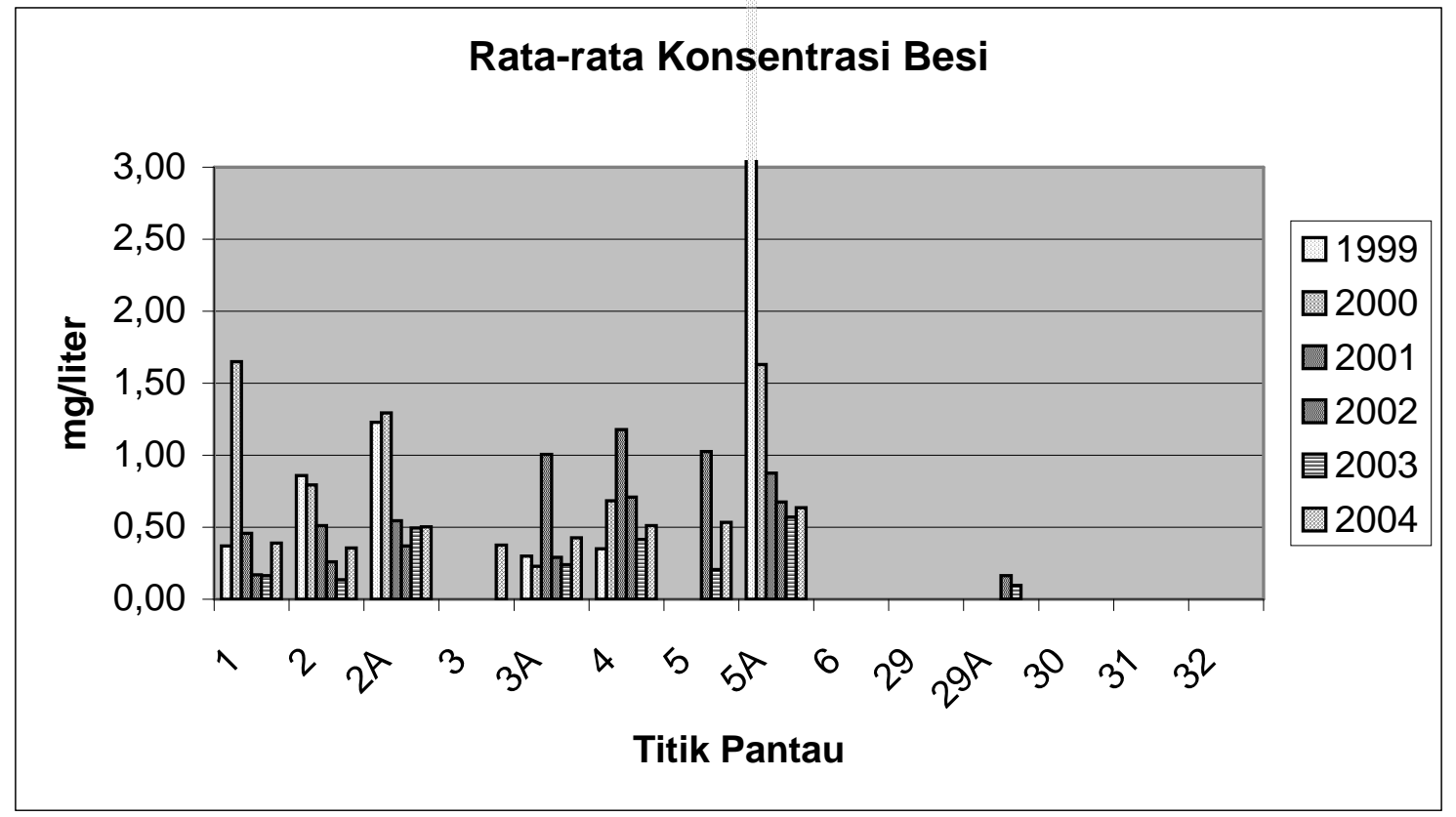

Gambar 3 : Rata-rata Konsentrasi Besi (Fe) di Titik Pantau Sepanjang Sungai Ciliwung

\subsection{Kandungan Logam Berat di sungai Cipinang}

Sungai Cipinang menurut Keputusan Gubernur Provinsi DKI Jakarta Nomor 582 tahun
1995 merupakan sungai dengan peruntukkan pertanian dan usaha perkotaan (Golongan D). Dari data yang terkumpul, ada empat logam berat yang terdapat di sungai Cipinang, yaitu air raksa, tembaga, mangan dan seng. 


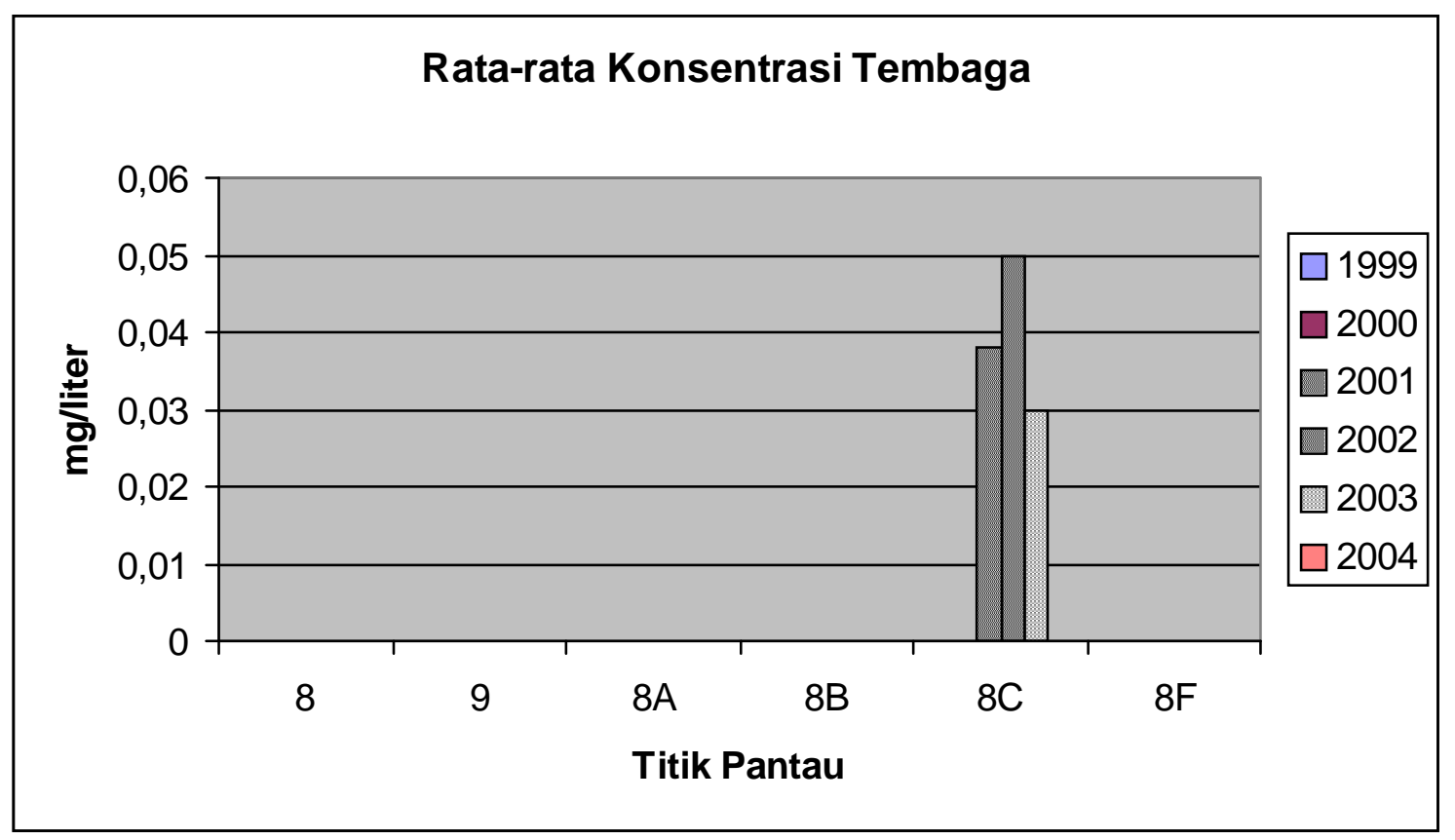

Gambar 4 : Rata-rata Konsentrasi Tembaga di Titik Pantau Sepanjang Kali Cipinang

Konsentrasi tembaga (Gambar 4) hanya terdapat di titik $8 \mathrm{C}$ dan konsentrasinya masih memenuhi baku mutu yang ada. Untuk logam mangan (Gambar 5) terjadi pencemaran pada tahun $2000-2002$ dengan konsentrasi tertinggi di titik 8 dan $8 \mathrm{C}$. Konsentrasi seng mengalami peningkatan pada tahun 2001 dan 2003 di titik 8 dan $8 \mathrm{C}$ yang kadarnya telah melebihi baku mutu yang ada. Untuk air raksa hanya terdapat di titik 8C tahun 2000 yaitu sebesar $0,03 \mathrm{mg} / \mathrm{L}$ dan sudah melebihi baku mutu yang telah ditetapkan oleh pemerintah yaitu $0,005 \mathrm{mg} / \mathrm{L}$. Hal ini sangat berbahaya bagi kehidupan, baik bagi organisme akuatik maupun bagi manusia bila masuk ke dalam rantai makanan. Dari keterangan di atas dapat dilihat bahwa kandungan logam berat dengan konsentrasi tinggi terdapat di titik 8 dan 8C, hal ini diduga karena banyaknya industri yang terdapat disekitar lokasi yang membuang limbahnya ke sungai Cipinang tanpa diolah terlebih dahulu, selain itu padatnya penduduk yang tinggal di sekitar DAS Cipinang. Sumber sumber pencemar sungai Cipinang yang berasal dari proses aktifitas pabrik/industri, baik yang skala besar maupun industri rumah tangga, juga dari kawasan komersial dan perkantoran. Air limbah industri tersebut mengandung zat organik, anorganik, logam-logam dan logam berat yang merupakan parameter-parameter pencemar yang sangat berat.

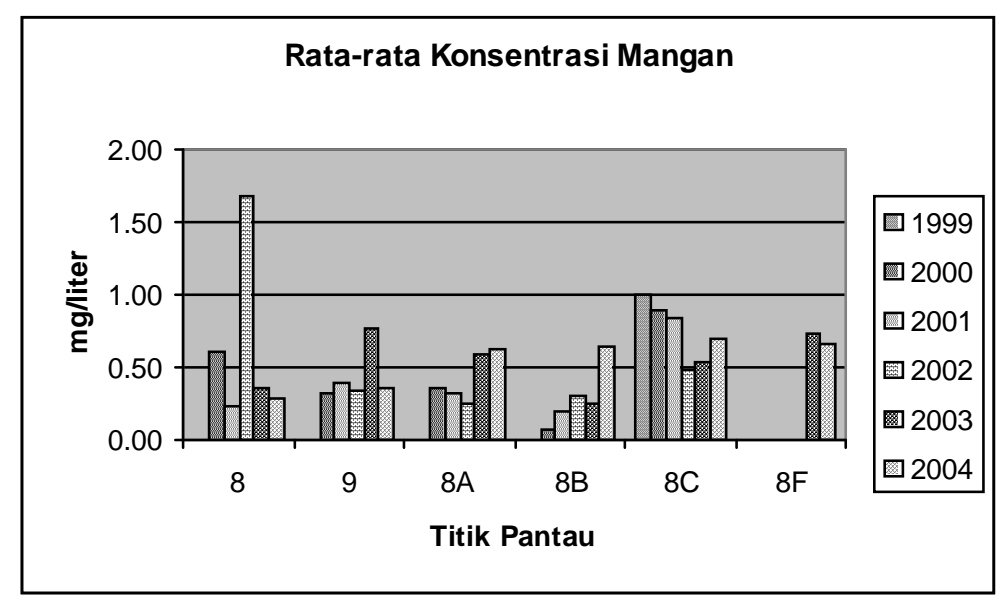

Gambar 5 : Rata-rata Konsentrasi Mangan Titik Pantau Sepanjang Kali Cipinang. 
Adapun lokasi-lokasi industri yang terdapat disepanjang DAS sungai Cipinang dapat dilihat pada Tabel 1. Belum semua industri teridentifikasi karena minimnya data, saat ini baru teridentifikasi industri yang berada di DAS sungai Cipinang, yang terdiri atas industri elektronika, industri makanan (biskuit, susu, makanan bayi), industri obat dan bahan kimia, tekstil, kosmetik, baterai, cat, logam dan masih banyak lagi. Dari sekian banyak industri tersebut industri yang mempunyai potensi sebagai sumber pencemaran adalah industri tekstil, elektronika, makanan dan bahan kimia.

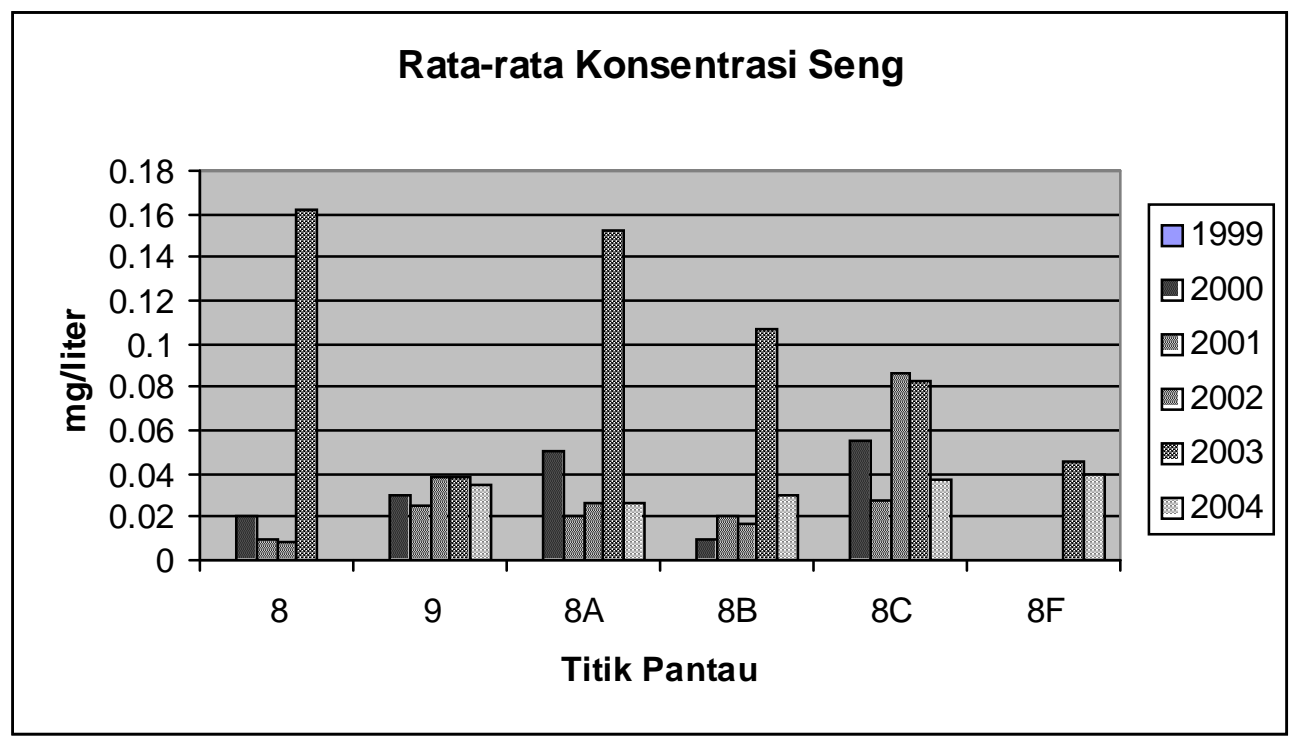

Gambar 6 : Rata-rata Konsentrasi Seng Titik Pantau Sepanjang Kali Cipinang.

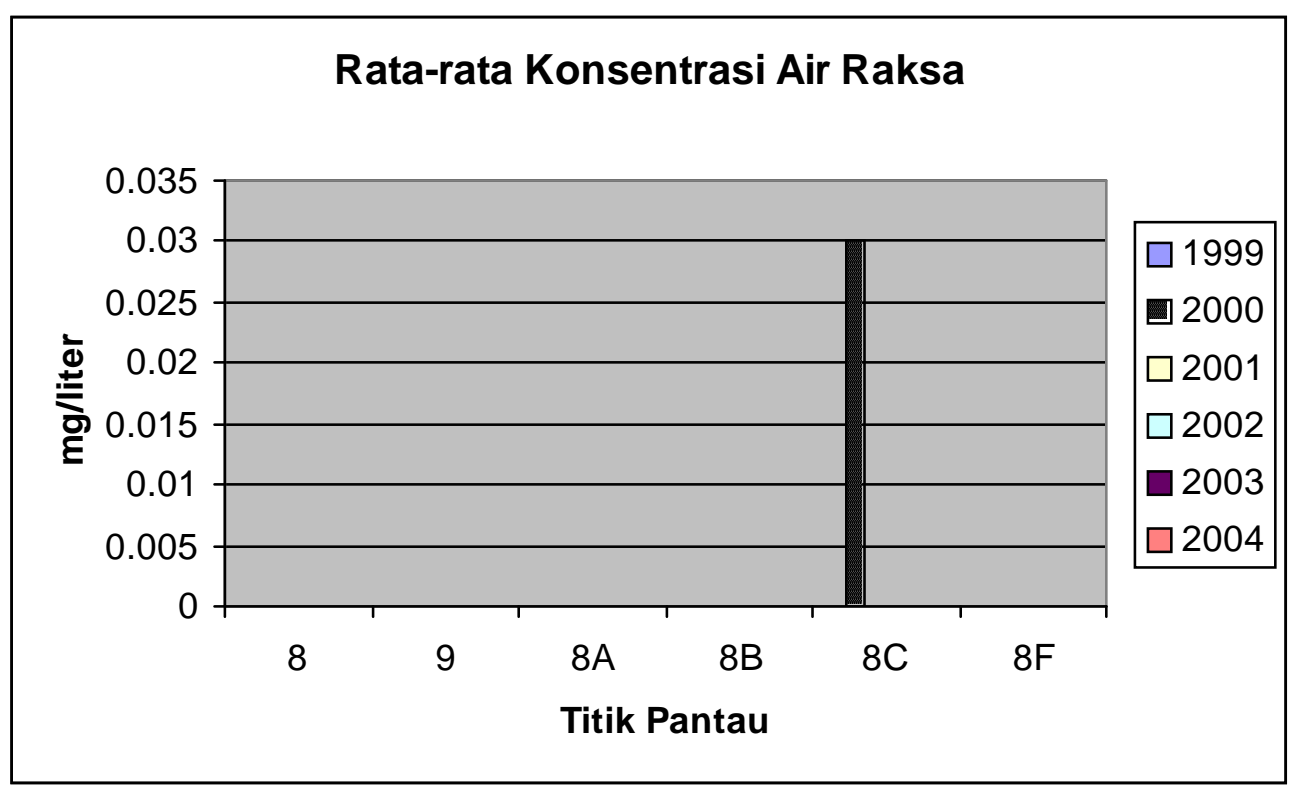

Gambar 7: Rata-rata Konsentrasi Air Raksa Titik Pantau Sepanjang Kali Cipinang.

\subsection{Kondisi Logam Berat di Sungai Sunter}

Dari hasil pemantauan dari tahun 1999 2004, ada tiga logam berat yang terdapat di sungai Sunter, yaitu mangan, seng dan tembaga. Sungai Sunter juga merupakan sungai dengan peruntukkan pertanian dan usaha perkotaan
(Golongan D). Kandungan tembaga hanya terdapat pada tahun 1999 - 2001 dengan konsentrasi yang rendah yaitu $0,03-0,06 \mathrm{mg} / \mathrm{L}$ di titik 45,10 dan $11 \mathrm{~A}$ sedangkan di titik yang lainnya tidak terdapat (tidak terdeteksi).

Untuk logam mangan terlihat ada peningkatan dari tahun ke tahunnya dan kembali 
mengalami penurunan pada tahun 2004 (masih dibawah baku mutu). Konsentrasi mangan tertinggi terjadi pada Juli 2002 di titik 11, karena titik ini merupakan pertemuan dengan aliran sungai Tarum Barat yang banyak membawa limbah - limbah yang mengandung logam berat. Di titik 11A (tahun 2001) konsentrasi mangan juga tinggi, disini terdapat aliran dari sungai Cipinang yang kemungkinan juga berperan dalam meningkatkan kadar logam mangan.
Untuk parameter logam seng dari tahun ke tahun konsentrasinya masih tetap berada di bawah baku mutu yang ada, kecuali pada tahun 2001 di titik 10 terjadi kondisi yang sangat ekstrem yaitu konsentrasi sengnya mencapai $12,44 \mathrm{mg} / \mathrm{L}$. Hal ini diduga karena kecilnya debit aliran sungai karena musim kemarau sehingga kandungan logam beratnya tertumpuk di daerah tersebut.

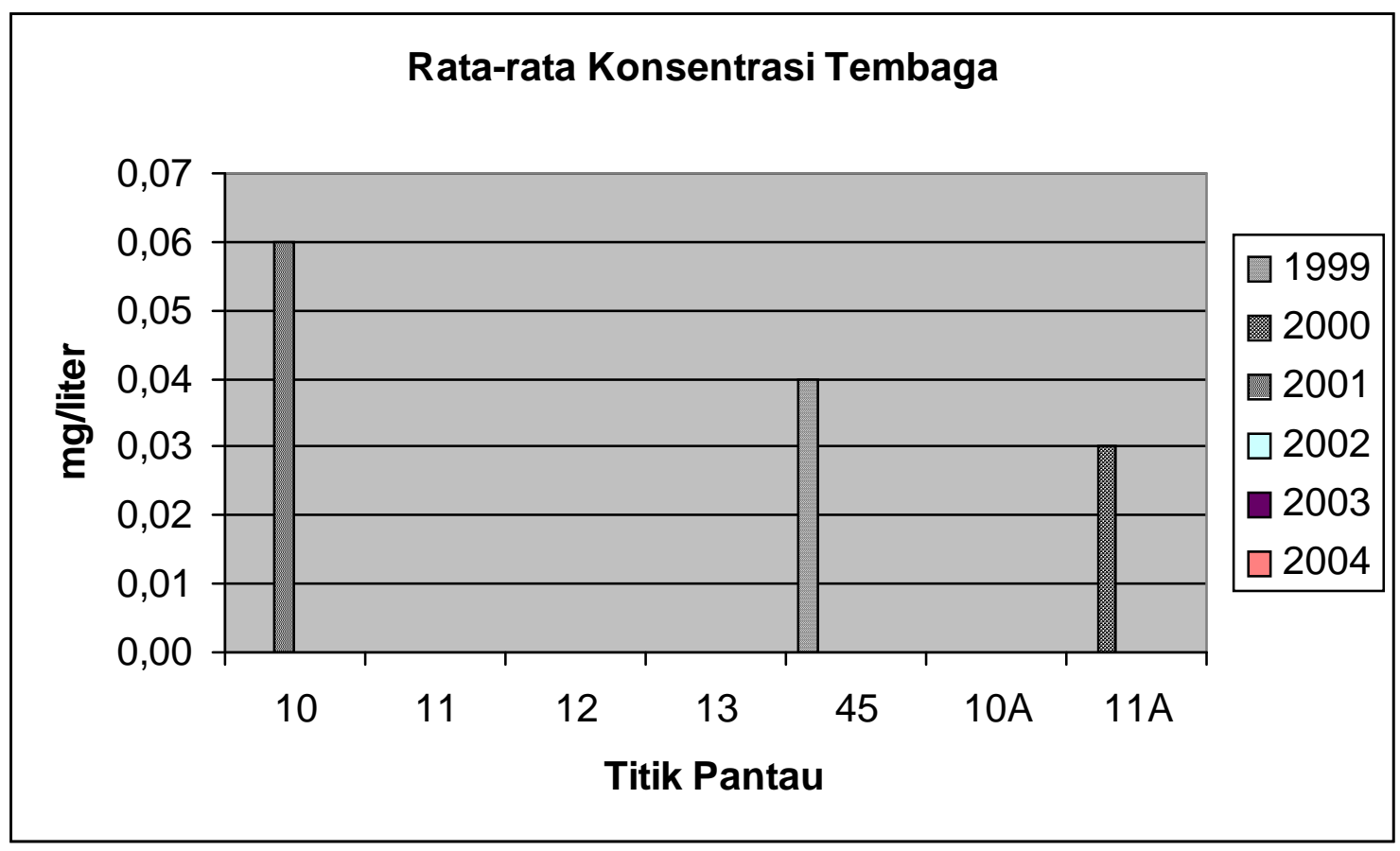

Gambar 8 : Rata-rata Konsentrasi Tembaga di Titik Pantau Sepanjang Kali Sunter.

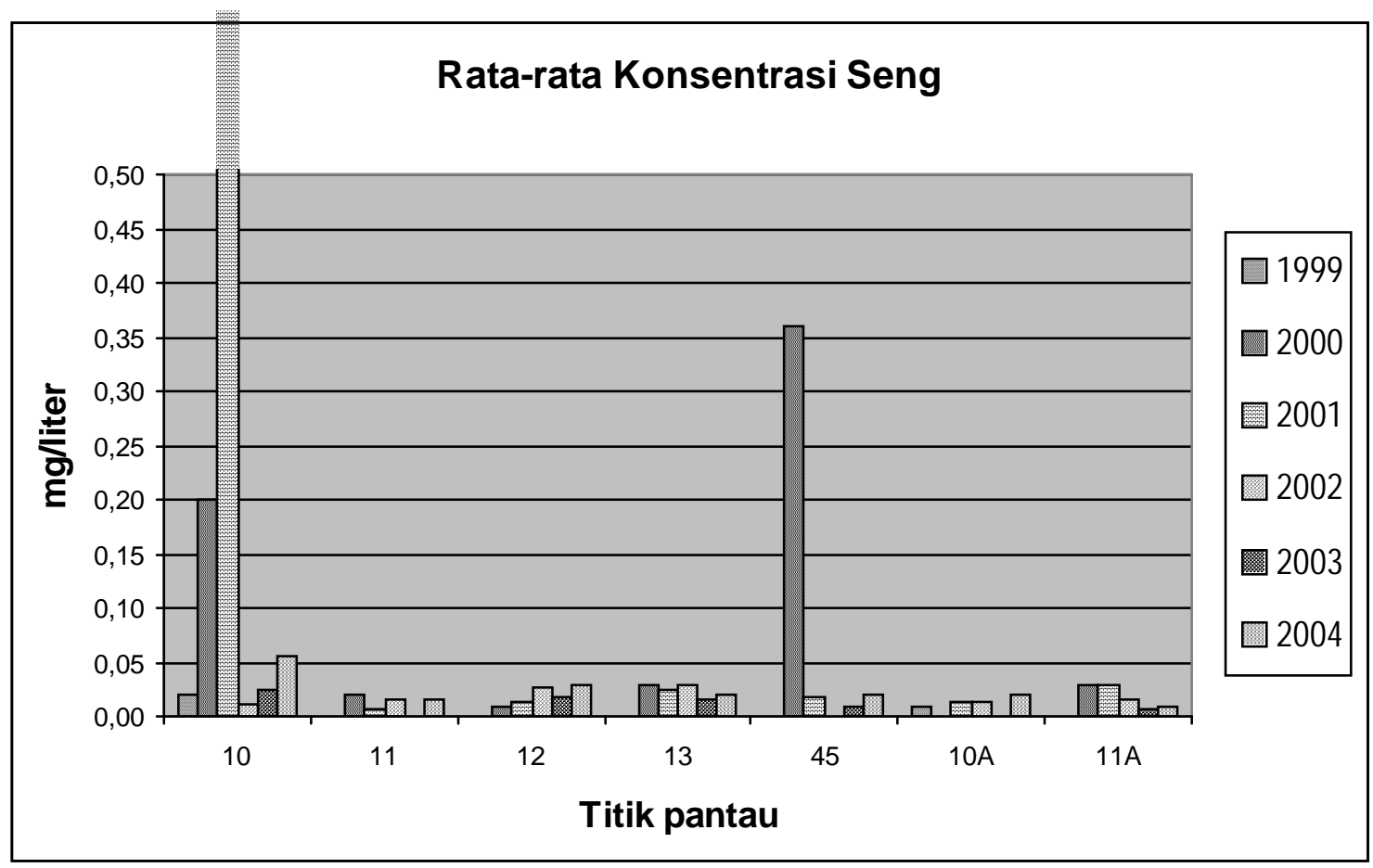

Gambar 9 : Rata-rata Konsentrasi Seng di Titik Pantau Sepanjang Kali Sunter. 


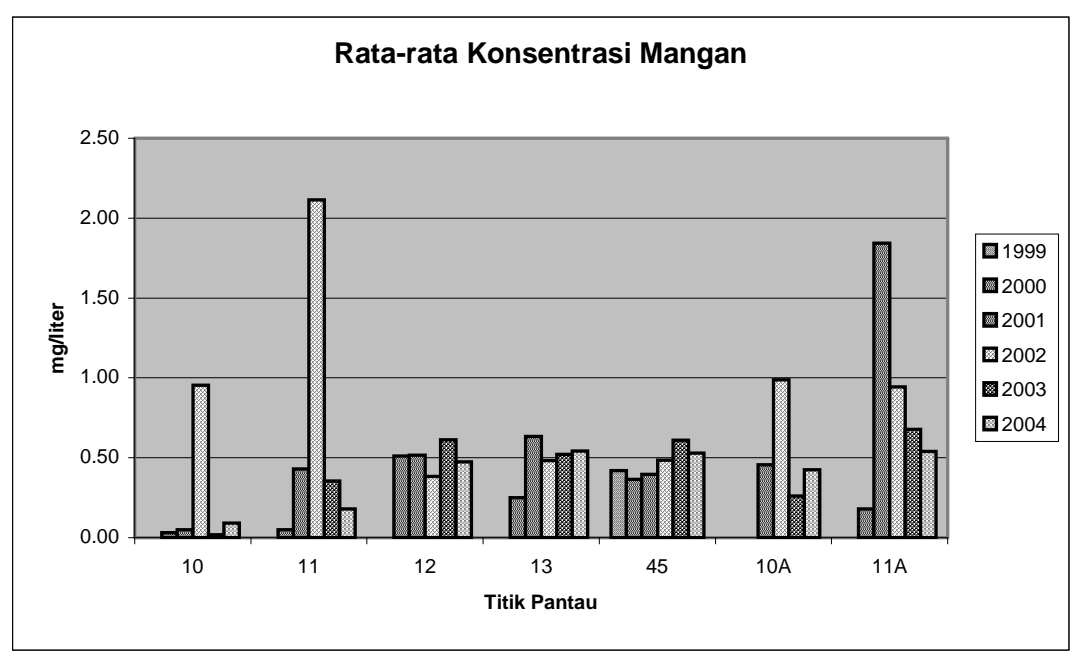

Gambar10 : Rata-rata Konsentrasi Mangan di Titik Pantau Sepanjang Kali Sunter.

\subsection{Kondisi Logam Berat di sungai Grogol}

Pada sungai Grogol terdapat empat lokasi pemantauan yang tersebar dari hulu ke hilir. Sungai Grogol termasuk dalam golongan C (25, 25A, 26) dan golongan D (27). Dari hasil pemantauan ada empat logam berat yang terdapat di sungai Grogol yaitu $\mathrm{Mn}, \mathrm{Ni}, \mathrm{Hg}$ dan $\mathrm{Zn}$.

Dari grafik dapat dilihat bahwa kandungan logam mangan selalu ada di titik 27 dan kandungannya lebih tinggi pada bulan Juli dari pada April dan Nopember walaupun konsentrasinya masih tergolong rendah (masih berada di bawah baku mutu). Hal ini dimungkinkan karena di bulan Juli yang merupakan musim kemarau menjadikan sungai mendapatkan masukan air yang sedikit sehingga air yang terdapat di sungai hanya berasal dari lokasi tersebut dan masukan limbah dari sumber pencemar menjadi tidak teralirkan karena rendahnya debit.

Untuk logam seng kadarnya meningkat dari tahun 1999 - 2000. Pada tahun 1999 kandungan seng yang tinggi terdapat di titik 25 $(0,09 \mathrm{mg} / \mathrm{L})$ yang sudah melebihi baku mutu untuk seng yaitu $0,05 \mathrm{mg} / \mathrm{L}$ (Golongan C). Pada tahun 2000 mengalami peningkatan hampir di semua titik dan telah melebihi baku mutu (pada bulan Juli) kecuali di titik 27 kadarnya sangat kecil $(0,01 \mathrm{mg} / \mathrm{L})$. Pada tahun 2001 hanya di titik 25 yang kadarnya melebihi baku mutu sedangkan titik yang lainnya relatif rendah. Pada tahun berikutnya $(2002$ - 2004) konsentrasinya tidak ada yang melebihi baku mutu di setiap titik.

Untuk konsentrasi $\mathrm{Hg}$ hanya terdapat di titik 25 dan 25A pada tahun 1999 dan tergolong tercemar ringan karena hanya sedikit melebihi baku mutu yang ditetapkan. Konsentrasi $\mathrm{Ni}$ hanya terdapat di titik 25 pada tahun 2003, tetapi kadarnya sangat kecil yaitu $0,01 \mathrm{mg} / \mathrm{L}$.

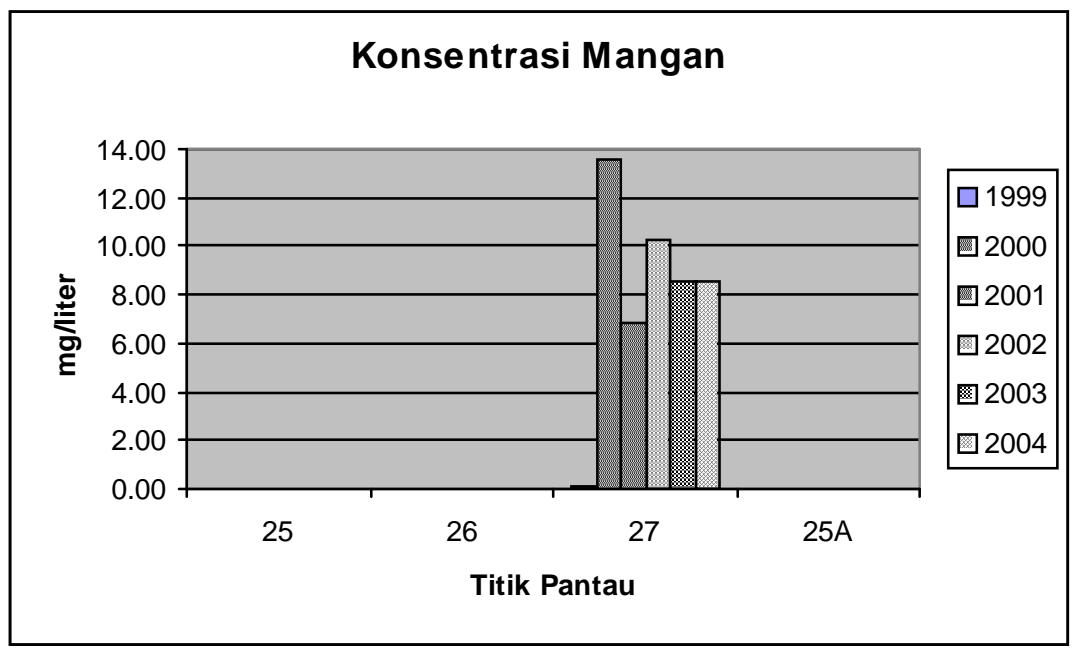

Gambar 11: Rata-rata Konsentrasi Mangan di Titik Pantau Sepanjang Kali Grogol. 


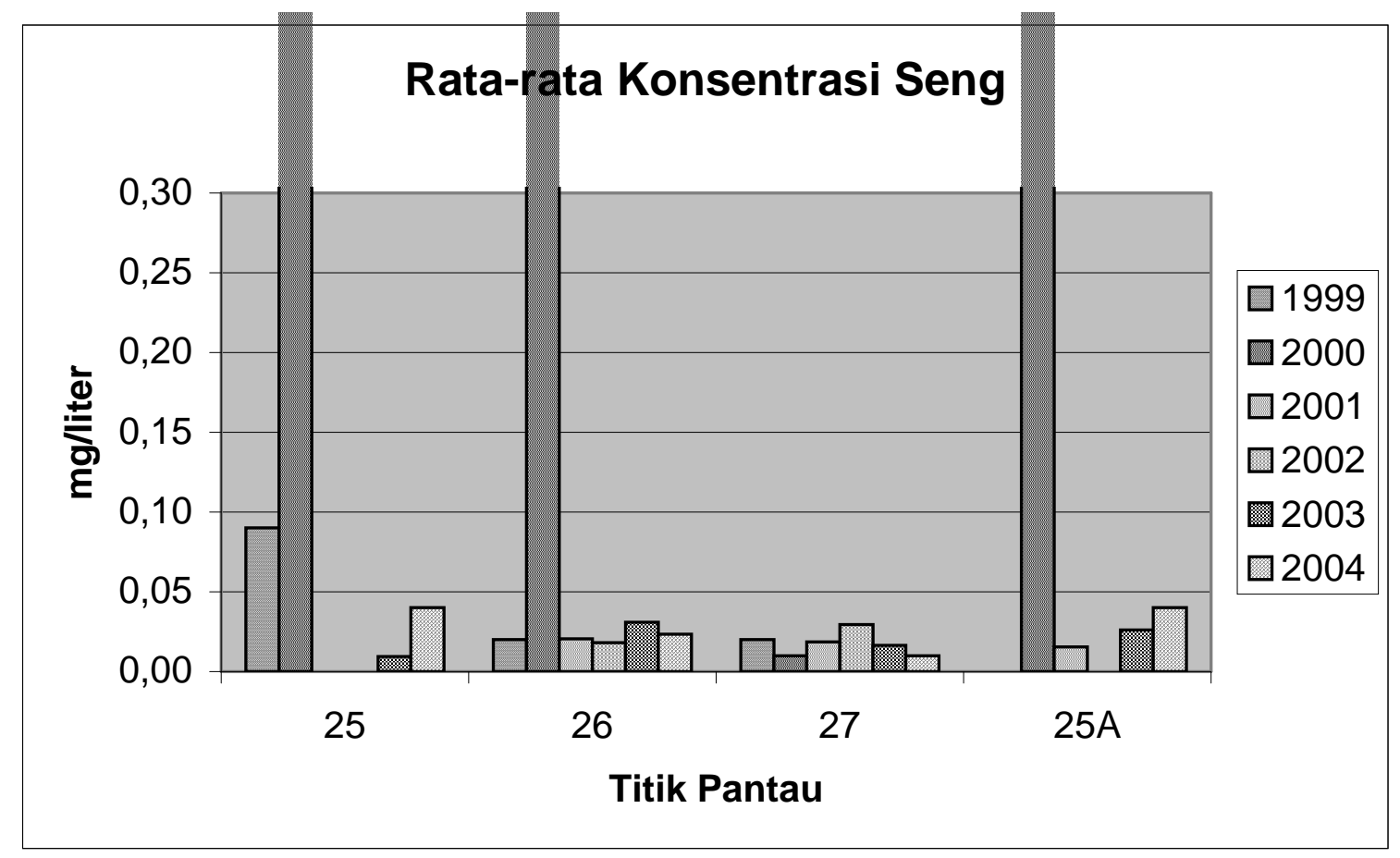

Gambar 12 : Rata-rata Konsentrasi Seng di Titik Pantau Sepanjang Kali Grogol.

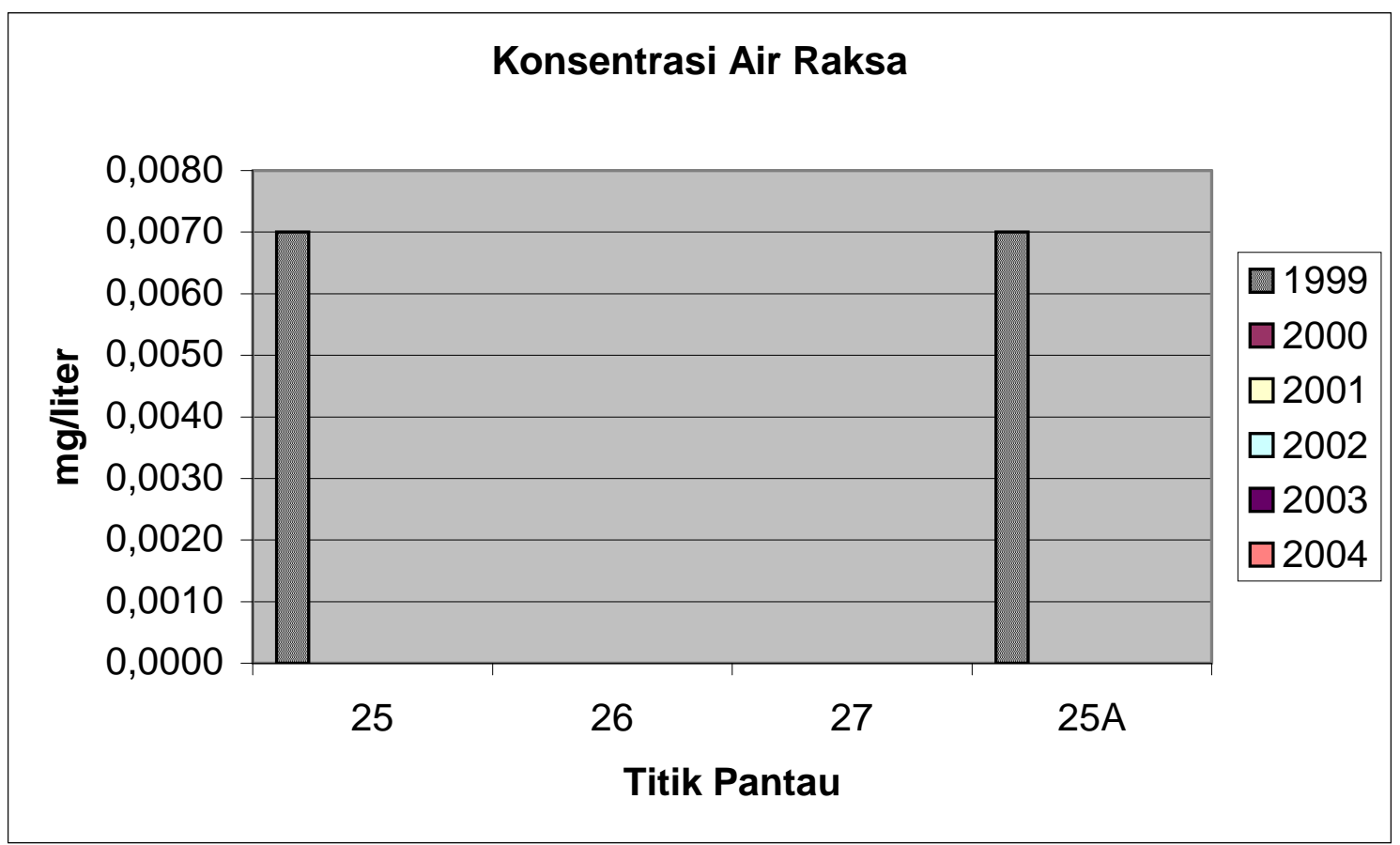

Gambar 13 : Rata-rata Konsentrasi Air Raksa, di Titik Pantau Sepanjang Kali Grogol.

\subsection{Kondisi Logam Berat di Sungai Mookervart}

Di sungai Mookervart terdapat lima titik pemantauan dan tergolong dalam sungai dengan peruntukkan perikanan dan peternakan (Golongan C). Terdapat tiga logam berat yang terdeteksi di dalam air sampel yang berasal dari air sungai Mookervart yaitu seng (Zn), tembaga (Cu) dan khrom (Cr) (Tabel 5.).

Untuk logam seng, dari tahun ke tahunnya selalu terdapat titik yang konsentrasinya melebihi baku mutu yang ada. Konsentrasi yang ekstrem terjadi di titik 24B pada Juli 2001 yaitu 42,62 
$\mathrm{mg} / \mathrm{L}$. Hal ini di duga terjadi karena adanya industri (baik industri kecil maupun rumah tangga) yang membuang limbah yang banyak mengandung logam seng ke sungai tanpa di olah terlebih dahulu ditambah dengan musim kemarau yang menyebabkan aliran airnya tidak mengalir dengan baik, sehingga logam seg tertumpuk di titik tersebut.

Untuk logam tembaga hanya terdapat di titik 24 pada tahun 2001 dan 2003 yang kadarnya sedikit melebihi baku mutu yang ada. Sedangkan konsentrasi $\mathrm{Cr}$ hanya terdapat di titik 24D sebesar $0,14 \mathrm{mg} / \mathrm{L}$ yang melebihi baku mutu yang telah di tetapkan yaitu $0,05 \mathrm{mg} / \mathrm{L}$.

Masalah yang dihadapi sungai-sungai yang ada di Jakarta banyak sekali dan perlu mendapat penanganan segera yaitu Pencemaran oleh pemukiman yang berupa limbah cair dan sampah. Banyaknya pemukiman yang tumbuh sepanjang aliran sungai membawa masalah. Pada umumnya limbah dari pemukiman masuk ke sungai tanpa pengolahan. Di beberapa tempat nampak jelas sekali bahwa limbah pemukiman sudah waktunya untuk ditangani atau diolah sebelum masuk ke dalam perairan. Sampah padat sering menumpuk pada tikungan sungai bagian dalam dan dikolong jembatan. Sampah tersebut menggangu aliran dan pemandangan dan secara tidak langsung menyebabkan pendangkalan dan banjir di beberapa tempat untuk itu peningkatan kinerja pengelolaan sampah harus terus ditingkatkan. Selain itu juga pencemaran dapat disebabkan oleh industri yang berada dalam DAS baik industri kecil maupun industri rumah tangga Lokasi industri tersebut memerlukan suatu pengolahan limbah, perencanaan dan pembuatan IPAL terpadu untuk pemukiman dan industri.

Keadaan saat ini masing-masing industri membuang langsung limbahnya ke saluran umum, sehingga sulit untuk mengontrol limbahnya setiap waktu. Hanya saja masingmasing industri biasanya mempunyai limbah yang spesifik, oleh karena itu setiap industri sebaiknya mempunyai pengolahan awal yang mengolah limbah spesifik, misalnya: lemak, minyak, olie, logam berat, suspended solid tinggi. Dari pengolalahan awal tersebut baru masuk ke pengolahan kolektif

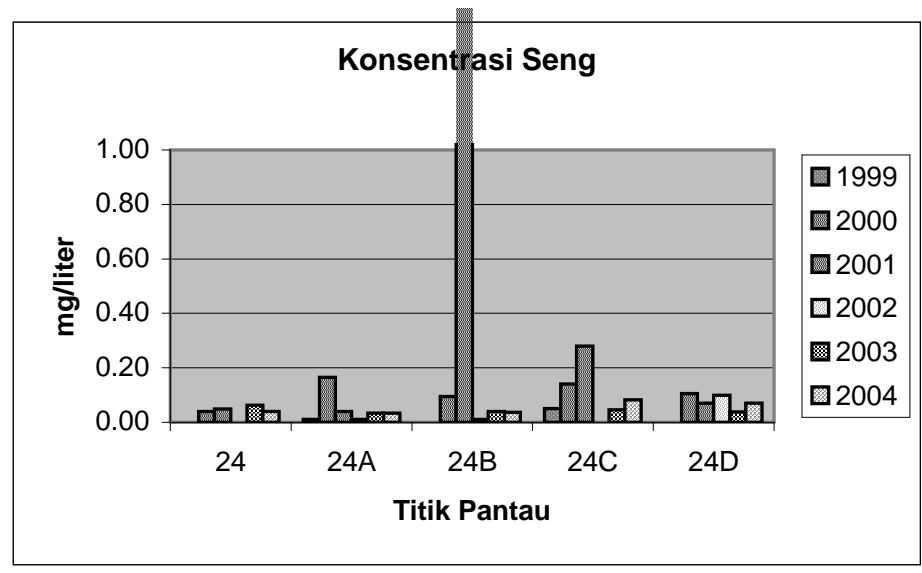

Gambar 14 : Rata-rata Konsentrasi Seng di Titik Pantau Sepanjang Kali Mookevart.

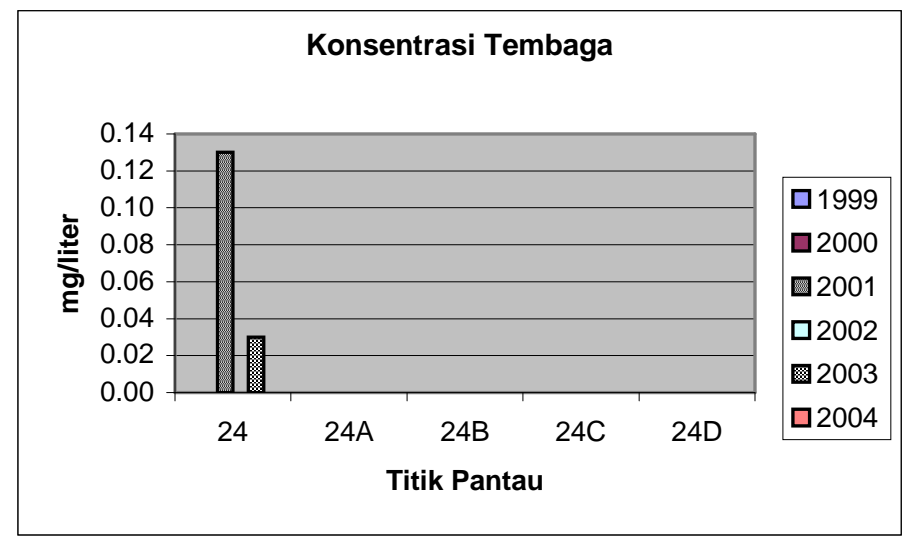

Gambar 15 : Rata-rata Konsentrasi Tembaga di Titik Pantau Sepanjang Kali Mookevart. 


\section{KESIMPULAN DAN SARAN}

\subsection{Kesimpulan}

- Pencemaran sungai di wilayah DKI Jakarta lebih tinggi musim kemarau, karena debit air sungai turun drastis, sedangkan volume kegiatan industri tetap, sehingga pencemaran yang dikeluarkan juga tetap.

- Pada umumnya pencemaran logam berat di perairan DKI Jakarta di sebabkan oleh limbah domestik yang berasal dari pemukiman dan limbah industri yang berada di DAS yang dibuang tanpa diolah terlebih dahulu.

- Di daerah pertemuan antara dua sungai atau lebih, kandungan logam beratnya relatif tinggi karena mendapat masukan limbah dari aliran sungai yang lain.

- Pada umumnya kondisi logam berat di perairan DKI Jakarta dari hulu ke hilir makin meningkat konsentrasinya.

\subsection{Saran}

- Identifikasi lebih lanjut perlu dilakukan oleh instansi yang berwenang terhadap industri yang berpotensi sebagai sumber pencemaran untuk memantau apakah limbahnya sudah dikelola dengan baik atau belum.

- Perlu adanya pemantauan secara berkala agar kondisi kandungan logam berat di perairan DKI Jakarta dapat diketahui secara berkesinambungan dan perlu adanya tindak lanjut dan upaya dalam menanggulangi pencemaran air sungai.

- Pada pemantauan selanjutnya sebaiknya dilengkapi dengan data lapangan atau kondisi fisik dari tiap-tiap lokasi titik pantau.

- Perlu adanya perencanaan dan pembuatan IPAL terpadu untuk pemukiman dan industri serta peningkatan kinerja pengelolaan sampah.

\section{DAFTAR PUSTAKA}

1. Darmono. 1995. Logam dalam Sistem Biologi Makhluk Hidup. Penerbit UI. Jakarta.

2. Darmono. 2001. Lingkungan Hidup dan Pencemaran : Hubungannya dengan Toksikologi Senyawa Logam. Penerbit UI. Jakarta.

3. Effendi, H. 2000. Telaahan Kualitas Air. Bogor: IPB.

4. Hutabarat, S dan S.M. Evans. 1986. Pengantar Oseanografi. Jakarta : UI Press.
5. Hutagalung, H.P. 1991. Pencemaran Laut oleh Logam Berat : Dalam Status Pencemaran Laut di Indonesia dan Teknik Pemantauannya. P3O-LIPI. Jakarta.

6. Nybakken, J.W. 1992. Biologi Laut; Suatu Pendekatan Ekologis. Jakarta : PT. Gramedia Pustaka Umum.

7. Palar, H. 1994. Pencemaran dan Toksikologi Logam Berat. Rineka Cipata. Jakarta.

8. Supriharyono, M.S. 2000. Pelestarian dan Pengelolaan Sumber Daya Alam di Wilayah Pesisir Tropis. PT. Gramedia Pustaka Utama. Jakarta. 


\section{LAMPIRAN :}

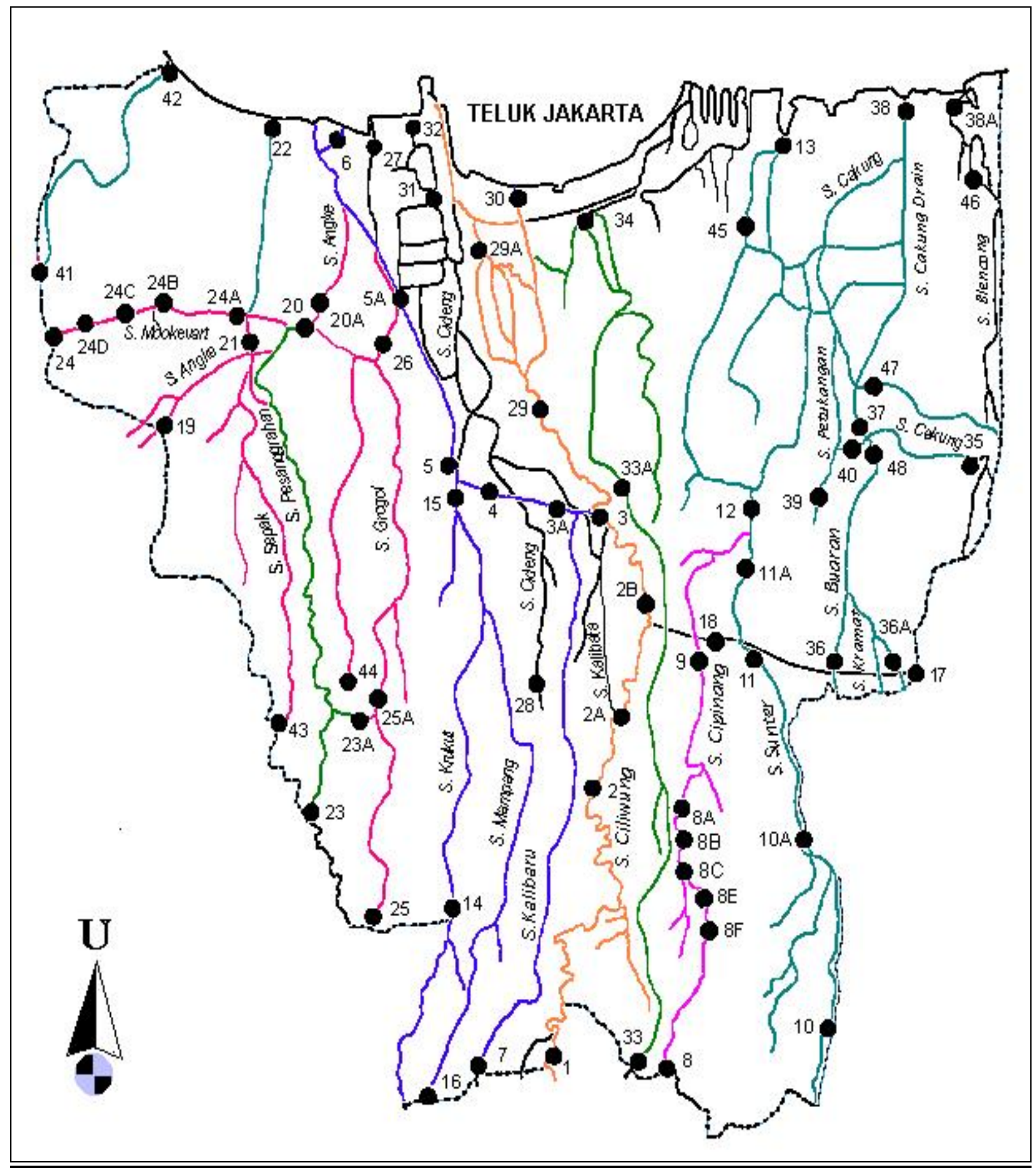

Gambar 16 : Lokasi Titik Pantau di sepanjang sungai/kali di Wilayah DKI Jakarta. 
Tabel 1: Industri di dalam DAS Kali Cipinang.

\begin{tabular}{|c|c|c|c|c|}
\hline NO. & $\begin{array}{l}\text { NAMA INDUSTRI } \\
\text { (PT) }\end{array}$ & $\begin{array}{c}\text { JENIS } \\
\text { INDUSTRI }\end{array}$ & LOKASI & $\begin{array}{l}\text { SALURAN } \\
\text { LIMBAH KE: }\end{array}$ \\
\hline 1. & CENTEX & TEXTIL & JL. CENTEX & Outlet situ jatijajar \\
\hline 2. & SCTI & TEXTIL & JL. CIRACAS RAYA & Outlet situ jatijajar \\
\hline 3. & KIWI INDONESIA & SEMIR & JL. KIWI RAYA & Outlet situ jatijajar \\
\hline 4. & DAIRYVILLE & & JL. KIWI RAYA & Outlet situ jatijajar \\
\hline 5. & GURU INDONESIA & & JL. KIWI RAYA & Outlet situ jatijajar \\
\hline 6. & $\begin{array}{l}\text { KARFILINDO ABD } \\
\text { INDONESIA }\end{array}$ & & JL. KIWI RAYA & Outlet situ jatijajar \\
\hline 7. & NGK BUSI INDONESIA & BUSI & JL. KIWI RAYA & Situ Rawa Kalong \\
\hline 8. & MUSTIKA TIRTA & & JL. MUSTIKA RATU & Situ Rawa Kalong \\
\hline 9. & MUSTIKA RATU & KOSMETIK & JL. MUTIKA RATU & Situ Rawa Kalong \\
\hline 10. & ARTOLITE & TEKSTIL & JL. NANGKA & Situ Rawa Kalong \\
\hline 11. & BAJA BRANA & LOGAM & JL. NANGKA & Situ Rawa Kalong \\
\hline 12. & TANG MAS & MINUMAN & JL. NANGKA & Outlet S Rw Kalong \\
\hline 13. & TOA GALVA & ELEKTRONIK & JL. NANGKA & Outlet S Rw Kalong \\
\hline 14. & TRIPLE ACE & TEKSTIL & JL. NANGKA & Outlet S Rw Kalong \\
\hline 15. & EBARA INDONESIA & POMPA & JL. PEKAPURAN & Outlet S Rw Kalong \\
\hline 16. & MODERN FURNITURE & FURNITURE & JL. PEKAPURAN & Outlet S Rw Kalong \\
\hline 17. & SARI MULTI UTAMA & PLASTIK & JL. PEKAPURAN & Outlet S Rw Kalong \\
\hline 18. & DETA PRASANTA & PERCETAKAN & JL. PONCOL & Situ Gadog \\
\hline 19. & DWI SATRYA UTAMA & & JL. PONCOL & Situ Gadog \\
\hline 20. & KDS & & JL. PONCOL & Situ Gadog \\
\hline 21. & PUNCAK GUNUNG MAS & MAKANAN & JL. PONCOL & Situ Tipar \\
\hline 22. & SANYO & ELEKTRONIK & JL. RAYA BOGOR & Situ Tipar \\
\hline 23. & ICI PAINT & CAT & JL. RAYA BOGOR & Situ Tipar \\
\hline 24. & INDARGO & & JL. RAYA BOGOR & Situ Tipar \\
\hline 25. & KOADES INDONESIA & TINTA & JL. RAYA BOGOR & Situ Tipar \\
\hline 26. & AMCOL GRAHA ELEC & ELEKTRONIKA & JL. RAYA BOGOR & Situ Tipar \\
\hline 27. & ARCO & & JL. RAYA BOGOR & Situ Tipar \\
\hline 28. & ASIA INTI SELERA & & JL. RAYA BOGOR & Situ Tipar \\
\hline 29. & BAMBU MAS INDAH & & JL. RAYA BOGOR & Situ Tipar \\
\hline 30. & BAYER INDONESIA & OBAT & JL. RAYA BOGOR & K Cipinang \\
\hline 31. & BENTOEL & ROKOK & JL. RAYA BOGOR & K Cipinang \\
\hline 32. & BINA SATWA & & JL. RAYA BOGOR & K Cipinang \\
\hline 33. & BINTANG MAS & & JL. RAYA BOGOR & K Cipinang \\
\hline 34. & CANDRA SARI & & JL. RAYA BOGOR & K Cipinang \\
\hline 35. & CIBA GEICY & OBAT & JL. RAYA BOGOR & K Cipinang \\
\hline 36. & CICERO INDONESIA & & JL. RAYA BOGOR & K Cipinang \\
\hline 37. & DETTA MARINA & & JL. RAYA BOGOR & K Cipinang \\
\hline 38. & DUMEX INDONESIA & OBAT & JL. RAYA BOGOR & K Cipinang \\
\hline 39. & ENKA PRAHYANGAN & & JL. RAYA BOGOR & K Cipinang \\
\hline 40. & EVEREADY & BATTEREY & JL. RAYA BOGOR & K Cipinang \\
\hline 41. & FOREMOST INDONESIA & SUSU & JL. RAYA BOGOR & K Cipinang \\
\hline 42. & $\begin{array}{l}\text { FRIESCHE FLAG } \\
\text { INDONESIA }\end{array}$ & SUSU & JL. RAYA BOGOR & K Cipinang \\
\hline 43. & HENKEL INDONESIA & KIMIA & JL. RAYA BOGOR & K Cipinang \\
\hline 44. & $\begin{array}{l}\text { INDFARM } \\
\text { PEMBANGUNAN }\end{array}$ & & JL. RAYA BOGOR & K Cipinang \\
\hline 45. & INDO SEPA & TEKXTIL & JL. RAYA BOGOR & K Cipinang \\
\hline 46. & INDOMARCO & & JL. RAYA BOGOR & K Cipinang \\
\hline
\end{tabular}

